ISSN 2466-2232 (Print)

ISSN 2466-2100 (Online)

\title{
$\mathrm{Ti}$ 및 Ti-6Al-4V GTAW 클래딩의 미세조직 구성 및 상분석
}

\author{
최병학*^ ${ }^{*}$ 이상우* 임태운** 김청인 ${ }^{* * *}$ - 김재휘*** \\ *강릉원주대학교 신소재금속공학과 \\ ${ }^{* *} \mathrm{GS}$ 건설 \\ ***(주)클래드코리아
}

\section{Microstructure and Phase Analysis of Pure Ti and Ti-6Al-4V GTAW Cladding Material}

Byung Hak Choe*,†, Sang-Woo Lee*, Tae-Woon Lim**, Chung-In Kim*** and Jae-Hwi Kim***

*Dept. of Metal and Materials Engineering, Gangneung-wonju National Univ., Gangneung, 25457, Korea

**GS E\&C, Seoul, 03159, Korea

$* * *$ CladKorea, Wonju, 26365, Korea

†Corresponding author: cbh@gwnu.ac.kr

(Received December 4, 2019 ; Revised December 10, 2019 ; Accepted February 24, 2020)

\begin{abstract}
The microstructure and phase configuration of pure Ti and Ti-6Al-4V GTAW cladding were studied. The cladding microstructures were divided into the base metal $(\mathrm{BM})$ of the substrate, the heat affected zone (HAZ) and weld metal (WM). Depending on the location, the microstructure shape was observed to differ due to heat transfer effects, and the HAZ had a relatively fine structure due to fast cooling of the substrate contact. The lamellar spacing was $5 \mu \mathrm{m}$ for HAZ, which is smaller than the $10 \mu \mathrm{m}$ of WM. In the pure $\mathrm{Ti}$, the microstructure compositions consisted of a lamellar structure with a pure $\mathrm{Ti} \alpha$ phase and a rich $\mathrm{Fe} \beta$ phase, where $\mathrm{Fe}$ is an impurity segregated in the $\beta$ phase. In the Ti-6Al-4V, the microstructure compositions consisted of a lamellar structure with a lean $\mathrm{V}$ content of $\alpha$ phase and a rich $\mathrm{V}$ content of $\beta$ phase. The hardness values for pure $\mathrm{Ti}$ and $\mathrm{Ti}-6 \mathrm{Al}-4 \mathrm{~V}$ were measured and found to be $425 \mathrm{HV}$ and $259 \mathrm{HV}$, respectively.
\end{abstract}

Key Words : Pure Ti, Ti-6Al-4V, GTAW cladding, microstructure, HAZ, a and $\beta$ phase

\section{1. 서 론}

$\mathrm{Ti}$ 및 $\mathrm{Ti}$ 합금의 GTAW (gas tungsten arc weld) 를 이용한 클래딩은 용접의 미세조직 구성에 따라 기계 적 특성이 달라진다. 일반적으로 용접의 미세조직은 $\mathrm{FZ}$ (fusion zone), HAZ (heat affected zone) 및 BM (base metal)로 구분되는데, 클래딩의 공정 조건은 용 접 $\mathrm{FZ}$ 및 $\mathrm{HAZ}$ 조직 구성을 변화시키고 이에 따라 기계 적 특성이 결정되는 것이다. 일례로 순수 $\mathrm{Ti}$ (grade 2)
클래딩 조건에서 입력 전류와 산소 함량은 클래딩 용접 조직인 $a-c e l l$ 의 $a-l a t h$ 간격을 변화시키는 것으로 보고 된다 ${ }^{1,2)}$. 보고에 따르면 입력 전류가 높거나 산소 함량이 크면 래쓰 간격이 커지고 이에 따라 경도값이 감소하는 것으로 보고된다. 또한 $\mathrm{Ti}-6 \mathrm{Al}-4 \mathrm{~V}$ (grade 5) 클래딩 조건에서도 높은 입력 전류는 $\mathrm{a}-\mathrm{Widmanstatten} \mathrm{조직}$ 에 이르는 조대한 a-lath를 구성할 수 있고, 높은 가스 유체 속도는 입도를 작게 하여 기계적 특성을 개선하는 것으로 보고되고 있다 ${ }^{3,4)}$.

이러한 $\mathrm{Ti}$ 및 $\mathrm{Ti}-6 \mathrm{Al}-4 \mathrm{~V}$ 의 GTAW 클래딩 조건에

Journal of Welding and Joining, Vol.38 No.2(2020) pp166-172

https://doi.org/10.5781/JWJ.2020.38.2.6 
따르는 미세조직 구성은 입력 전류나 쉴딩 가스에 의한 가열 및 냉각 속도가 재질 용융과 응고 과정 중에 냉각 에 따른 합금 구성 상의 변태에 기인하는 것이다. 즉 $\mathrm{Ti}$ 합금이 가질 수 있는 구성 상으로써 기본적인 $\mathrm{a}$ 상과 $\beta$ 상 외에 급냉 상인 $a^{\prime}$ 마르텐사이트가 있을 수 있다. $a$ 상 은 클래딩 용접 조건에 의해 a-cell (platelet or basket weave) 또는 $a$ 마르텐사이트로 변태할 수 있으며, $a$

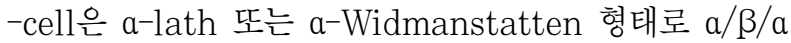
$/ \beta / \cdots$ 라멜라 구조를 이룬다. 이외에도 상은 조대한 입 상 입자로 입계 또는 입내에 존재할 수 있다 ${ }^{5,6)}$. 그리 고 이러한 $\mathrm{Ti}$ 합금 클래딩 미세조직이 경도나 인장과 같은 재질 기계적 특성에 영향을 미치는 것으로 보고되 고 있다 ${ }^{7,8)}$.이외에도 순수 $\mathrm{Ti}$ 클래딩 조건 중에서 산소 함량은 미세조직에 중요한 영향을 미치는데, 산소 함량 이 높을수록 a-lath 경계에 $\beta$ 상 잔존량이 커지며 조직 구 성 형태 및 기계적 특성을 결정짓는 것으로 보고된다.,10).

본 연구에서는 순수 $\mathrm{Ti}$ 및 Ti-6Al-4V 합금의 GTAW 클래딩 용접의 미세조직 구성과 상변태 양상을 고찰하 고자 하였다. 두 재질의 클래딩 조건은 주로 입도 (prior $\beta$ grain), $a$-lath 간격에 영향을 미첬으며, 이에 따른 경도값의 변화가 측정되었다. $\mathrm{Ti}$ 합금 클래딩 특성 개 선을 통해 추후 건전한 $\mathrm{Ti}$ 클래딩 제품 생산 공정에 기 여하고자 한다.

\section{2. 실험 방법}

순수 $\mathrm{Ti}$ 와 $\mathrm{Ti}-6 \mathrm{Al}-4 \mathrm{~V}$ GTAW 클래딩 재질 시제품 용접봉은 $2.4 \mathrm{~mm}$ 와이어의 ERTi-2 재질이며 1 layer 당 $3 \mathrm{~mm}$ 이하로 적층 클래딩 하도록 WPS에 명시된 다. 이러한 $\mathrm{Ti}$ 소재는 $300^{\circ} \mathrm{C}$ 부터 산화되므로 $200^{\circ} \mathrm{C}$ 이상에서 아르곤 숼딩 가스로 산화 억제를 수행해야 한 다. 클래딩 제품은 Fig. 1과 같이 지름 $(60) \times$ 높이 $(20) \times$ 두께 (4)이다. 클래딩은 $1 \mathrm{~kW}$ 출력으로 공정 변수는 피 드 공급 속도의 $2 \mathrm{~m} / \mathrm{min}$ 및 $5 \mathrm{~m} / \mathrm{min}$ 조건으로 설정하 고 시편을 제작하였다.

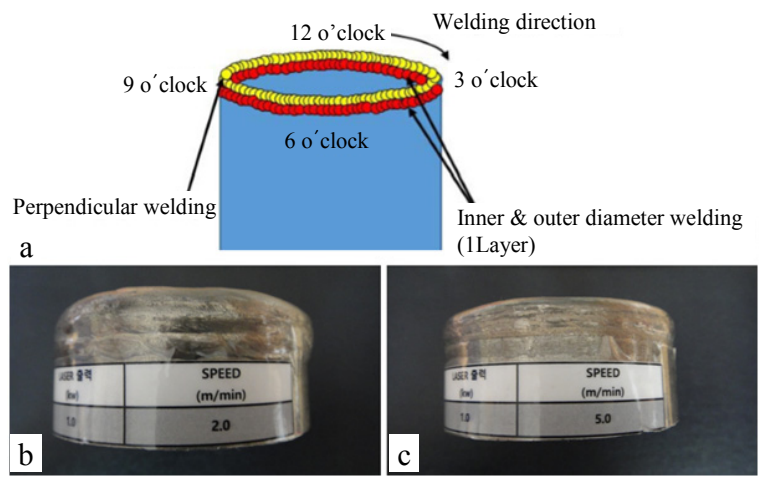

Fig. 1 Prototype of pure Ti GTAW claddin1g

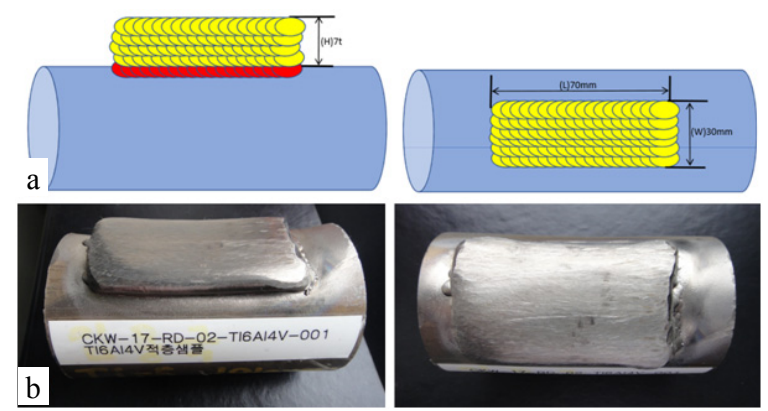

Fig. 2 Prototype of Ti-6Al-4V GTAW cladding

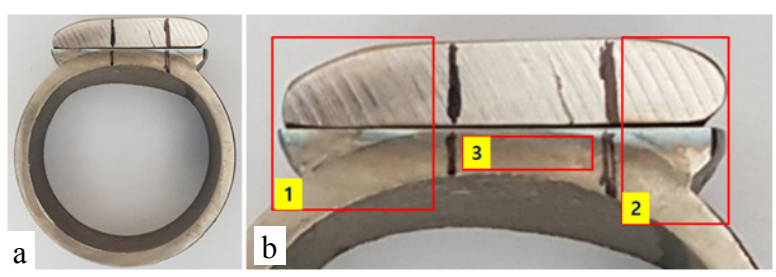

Fig. 3 Specimens taken from prototype of Ti-6Al-4V GTAW cladding

또한 Ti64 GTAW 클래딩 재질 시제품은 $2.4 \mathrm{~mm}$ 와이어 $\mathrm{ERTi}-5$ (Ti-6Al-4V 합금) 용접봉을 사용하였 는데, 클래딩 제품은 Fig. 2 와 같이 $\mathrm{W}(50) \times \mathrm{L}(70)$ $\times \mathrm{T}(7)$ 이며, 이를 통해 $\mathrm{Ti}-6 \mathrm{Al}-4 \mathrm{~V}$ 기판 위에 GTAW 클래딩 재질 시편을 제작하였다.

$\mathrm{Ti}-6 \mathrm{Al}-4 \mathrm{~V}$ 클래딩 재질 시편 미세조직 관찰과 경도 값 측정을 위하여 3 등분 하였는데, $\mathrm{FZ}$ 와 $\mathrm{HAZ}$ 분석을 위하여 Fig. 3과 같이 클래딩 양 옆 부위에서 1 번과 2 번 시료를 채취하였고, $\mathrm{BM}$ 은 중간의 3번 시료를 채취 하였다.

순수 $\mathrm{Ti}$ 와 $\mathrm{Ti}-6 \mathrm{Al}-4 \mathrm{~V}$ 클래딩 재질의 미세조직은 광 학 (OLYMPUS BX51M) 및 주사전자현미경 (JEOL $\mathrm{JP} / \mathrm{JSM}-7500 \mathrm{~F})$ 을 이용하여 관찰하였고 성분은 $\mathrm{EDS}$ (AMETEK EDAX ELITE)로 분석하였다. 또한 시편 각 미세조직 부위에 대한 비커스 경도 (Future Tech JP-FM-7)를 측정하였다. 또한 각 클래딩 재질에서 subsize 시험편을 채취하여 인장시험을 변형속도 $10^{-3} / \mathrm{sec}$ 조건에서 시행하였다.

\section{3. 실험 결과 및 고찰}

\section{1 순수 Ti (Grade 2) 및 Ti-6Al-4V (Grade 5) 인장특성 비교}

순수 $\mathrm{Ti}$ 와 $\mathrm{Ti}-6 \mathrm{Al}-4 \mathrm{~V}$ GTAW 클래딩 시편에 대한 인장특성은 Table 1,2 와 같이 측정되었다. Table 1 에 서 $\mathrm{Ti}$ 시편의 경우 $\mathrm{Ti}$ 클래딩 재질에 요구되는 항복/인 장강도 $580 \mathrm{MPa} / 600 \mathrm{MPa}$ 를 초과하는 값이며, 연신률 
Table 1 Tensile test properties of pure Ti GTAW cladding material specimens

\begin{tabular}{|c|c|c|c|}
\hline Specimen & Yield Stress & Tensile Stress & Elongation \\
\hline $2 \mathrm{~m} / \mathrm{min}$ & $\begin{array}{c}625 \mathrm{MPa} \\
(580 / 670)\end{array}$ & $\begin{array}{c}655 \mathrm{MPa} \\
(610 / 700)\end{array}$ & $22 \%(22 / 22)$ \\
\hline $5 \mathrm{~m} / \mathrm{min}$ & $\begin{array}{c}645 \mathrm{MPa} \\
(620 / 670)\end{array}$ & $\begin{array}{c}665 \mathrm{MPa} \\
(650 / 680)\end{array}$ & $17.5(22 / 13)$ \\
\hline
\end{tabular}

Table 2 Tensile test properties of Ti-6Al-4V GTAW material cladding specimens

\begin{tabular}{|c|c|c|c|}
\hline Specimen & Yield Stress & Tensile Stress & Elongation \\
\hline 1 & $1000 \mathrm{MPa}$ & $1080 \mathrm{MPa}$ & $38 \%$ \\
\hline 2 & $980 \mathrm{MPa}$ & $1000 \mathrm{MPa}$ & $25 \%$ \\
\hline
\end{tabular}

도 $17 \%$ 이상 값으로 측정되어 우수한 재질인 것을 알 수 있다. 또한 Table 2 에서 $\mathrm{Ti}-6 \mathrm{Al}-4 \mathrm{~V}$ 시편의 경우 $\mathrm{Ti}-6 \mathrm{Al}-4 \mathrm{~V}$ 클래딩 재질에 요구되는 항복/인장강도 $900 \mathrm{MPa} / 970 \mathrm{MPa}$ 를 초과하는 값이며, 연신률도 $25 \%$ 이상 값으로 측정되어 우수한 재질인 것을 알 수 있다.

\section{2 순수 Ti (Grade 2) 기판 모재 미세조직}

순수 $\mathrm{Ti}$ 및 $\mathrm{Ti}-6 \mathrm{Al}-4 \mathrm{~V}$ GTAW 클래딩 (공급 속도 $2 / \mathrm{min}$ 및 $5 \mathrm{~m} / \mathrm{min}$ )을 위해 기판은 두 재질 모두 순수 $\mathrm{Ti}$ 재질을 사용하였는데, 기판 모재의 미세조직은 Fig. 4와 같다. Fig. 4에서 미세조직은 a상으로 구성되었는 데 입계의 불순물 지역에 에칭에 의한 흑색 모습이 관 찰되며, 입자 크기는 약 $25 \mu \mathrm{m}$ 정도로 측정된다.

\section{3 순수 Ti (Grade 2) 클래딩 미세조직 및 경도}

순수 Ti GTAW 클래딩의 와이어 피드 공급 속도 변 수 $(2 / \mathrm{min} \& 5 \mathrm{~m} / \mathrm{min})$ 에 대한 위치별경도 측정 결과 는 Fig. 5 와 같다. 피드 공급 속도 $2 \mathrm{~m} / \mathrm{min}$ 의 Fig. 5 (a)에서 $\mathrm{FZ}$ (1)과 (2)의 경도값은 $243 \mathrm{HV}$ 및 $264 \mathrm{HV}$ 로 측정되었고, 피드 공급 속도 $5 \mathrm{~m} / \mathrm{min}$ 의 Fig. 5 (b)에 서 FZ (fusion zone) (1)과 (2)의 경도값은 $265 \mathrm{HV}$ 및

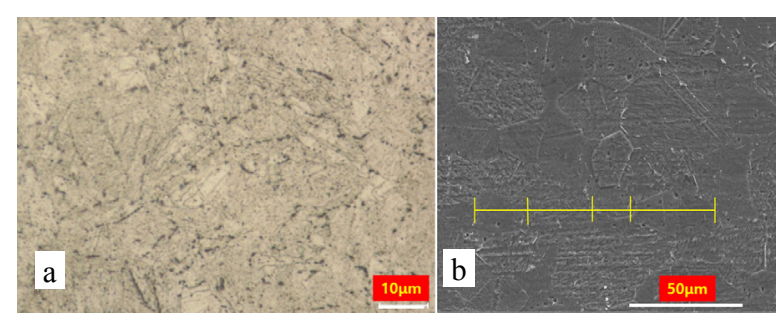

Fig. 4 Microstructures of prototype substrate for pure Ti and Ti-6Al-4V GTAW cladding : (a) OM, (b) SEM

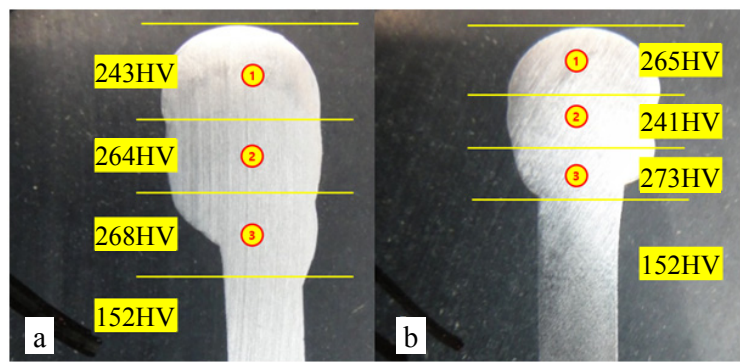

Fig. 5 Hardness values of pure Ti GTAW cladding : (a) $2 \mathrm{~m} / \mathrm{min}$ and (b) $5 \mathrm{~m} / \mathrm{min}$

$241 \mathrm{HV}$ 로 측정되어 공급속도나 용접부 위치별 경도값 차이는 거의 없는 것으로 파악된다. 또한 두 시편의 $\mathrm{HAZ}$ 경도값은 각각 $268 \mathrm{HV}$ 및 $273 \mathrm{HV}$ 로 측정되어 $\mathrm{FZ}$ 와 $\mathrm{HAZ}$ 경도도 큰 차이가 없는 것으로 판단된다. 클래딩 기판이 되는 모재의 경도는 순수 Ti에 해당하는 $152 \mathrm{HV}$ 로 측정된다.

피드 공급 속도 $2 \mathrm{~m} / \mathrm{min}$ 로 제조된 순수 Ti GTAW 클래딩 시편의 $\mathrm{FZ}$ 및 $\mathrm{HAZ}$ 미세조직은 Fig. 6와 같 다. Fig. 6 (a)에서 FZ 평균 입도는 $350 \mu \mathrm{m}$ 인 것으로 측정된다. 그리고 $\mathrm{FZ}$ 의 (1)과 (2)의 미세조직은 Fig. 6 (b) 및 (c)에서와 같이 $a-l a t h$ 형태의 $a / \beta / a / \beta \cdots$ 라멜 라 구조로 구성되는데, Fig. 6 에서 흰색의 각형은 $\alpha$ 상 이며 $a-l a t h$ 경계에 형성된 흑색 부위는 $\beta$ 상인 것을 알 수 있다. 이것은 순수 $\mathrm{Ti}$ 용접에서 산소 함량이 많 아지면 조직에 $\beta$ 상이 잔존하고 이것이 응고 냉각 중에 a-lath 경계에 집적하며 Fig. 6와 같은 라멜라의 적층 조직을 형성하는 것이다 ${ }^{9,10)} \mathrm{FZ}$ 부위인 (1)과 (2)의 a -lath 간격은 평균 $8 \mu \mathrm{m}$ 와 $10 \mu \mathrm{m}$ 로 측정된다. 그리고 $\mathrm{HAZ}$ 부위는 Fig. 6 (d)와 같이 FZ에 비하여 a-lath 형태가 길고 간격이 작게 관찰된다. 즉 $\mathrm{HAZ}$ a-lath 간격은 평균 $4 \mu \mathrm{m}$ 로써 $\mathrm{FZ}$ 에 비하여 반 정도로 간격이 감소하는 것을 알 수 있다.

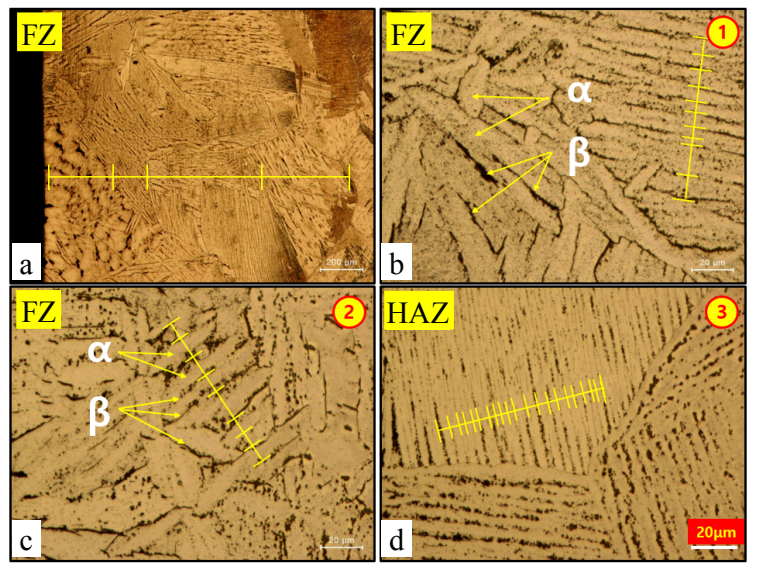

Fig. 6 Microstructures of pure Ti GTAW cladding for 2m/ min : (a),(b),(c) FZ and (d) HAZ 


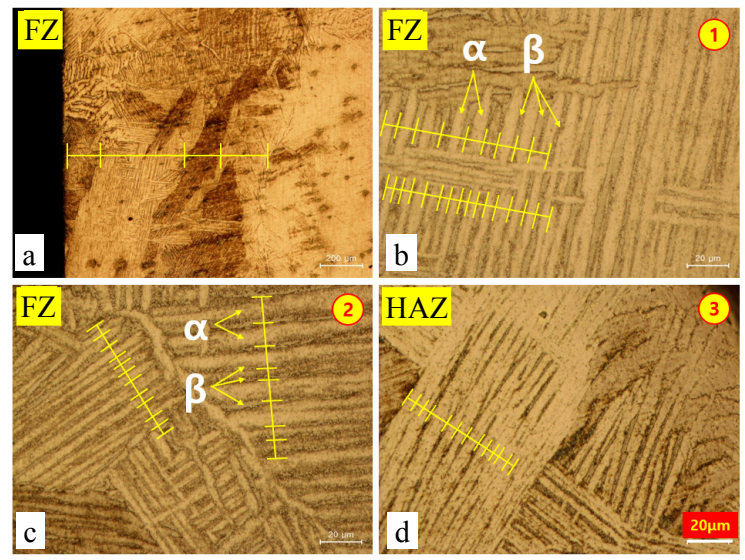

Fig. 7 Microstructures of pure Ti GTAW cladding for $5 \mathrm{~m} / \mathrm{min}:$ (a),(b),(c) FZ and (d) HAZ

이것에 비하여 피드 공급 속도 $5 \mathrm{~m} / \mathrm{min}$ 로 제조된 순 수 Ti GTAW 클래딩 시편의 FZ 및 $\mathrm{HAZ}$ 미세조직은 Fig. 7과 같다. Fig. 7 (a)에서 FZ 평균 입도는 피드 공급 속도 $2 \mathrm{~m} / \mathrm{min}$ 과 마찬가지로 $350 \mu \mathrm{m}$ 인 것으로 측 정된다. 그리고 $\mathrm{FZ}$ 의 (1)과 (2)의 미세조직도 피드 공급 속도 $2 \mathrm{~m} / \mathrm{min}$ 과 유사하게 Fig. 7 (b) 및 (c)에서와 같이 라멜라 구조로 구성된다. Fig. 7에서 흰색의 각형 은 $a$ 상이며 $a-l a t h$ 경계에 형성된 흑색 부위는 $\beta$ 상인 것을 알 수 있다.10). FZ 부위인 (1)과 (2)의 a-lath 간격 은 부분 평균 $5 \mu \mathrm{m} / 9 \mu \mathrm{m}$ 와 $5 \mu \mathrm{m} / 10 \mu \mathrm{m}$ 이며 전체 평균 $7 \mu \mathrm{m}$ 로 측정된다. 그리고 $\mathrm{HAZ}$ 부위의 미세조직도 피드 공 급 속도 $2 \mathrm{~m} / \mathrm{mim}$ 과 유사하게 Fig. 7 (d) 와 같이 FZ 에 비하여 a-lath 형태가 길고 간격이 작게 관찰된다. $\mathrm{HAZ} \mathrm{a-lath} \mathrm{간격은} \mathrm{평균} 5 \mu \mathrm{m}$ 로써 평균 $7 \mu \mathrm{m}$ 의 $\mathrm{FZ}$ 에 비하여 간격이 감소하는 것을 알 수 있다.

이러한 관찰로부터 순수 Ti GTAW 클래딩 미세조직 은 피드 공급 속도에 크게 영향을 받지 않고 a-lath 형 태의 라멜라 적층 구조인 것으로 확인된다. a-lath 간 격이 $\mathrm{FZ}$ 보다 $\mathrm{HAZ}$ 가 미세한 것은 클래딩 공정 중에 $\mathrm{HAZ}$ 부위로부터 모재 방향으로 열전달이 빨랐기 때문 인 것으로 보인다. 그러나 이와 같은 미세조직 차이가 경도에 큰 영향을 미치지는 않은 것으로 측정되었다.

\subsection{Ti-6Al-4V (Grade 5) 클래딩 마크로 조직 및 경도}

Fig. 3 (b)의 왼쪽 1 번과 오른쪽 2 번의 마크로 조직 및 경도 값은 Fig. 8과 같다. Fig. 8에서 두 시편의 클래딩 용접 부위는 클래딩 시 열전달 방향인 하부에서 상부 방향에 대한 방향성 응고 조직 구성이 관찰된다. 방향성 조직의 입도는 거의 용접부 $\mathrm{FZ}$ 부위를 관통하 는 평균 길이 $(10 \mathrm{~mm})$ 와 폭 $(2 \mathrm{~mm})$ 정도이며, 형상은

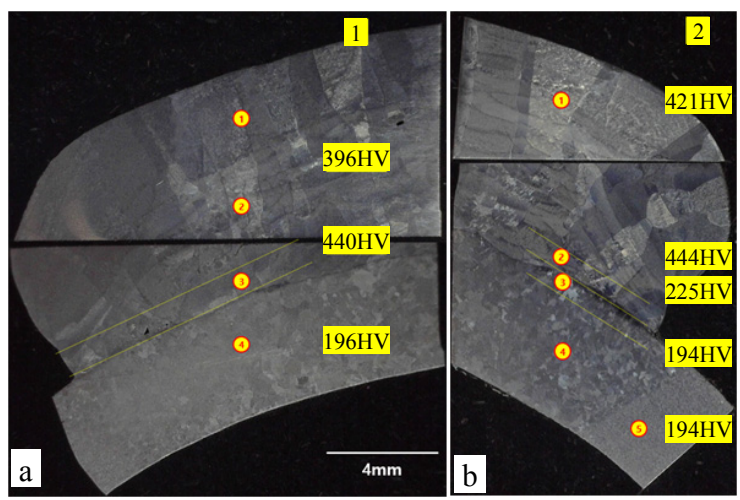

Fig. 8 Macrostructures and hardness values of Ti-6Al-4V GTAW cladding : (a) $2 \mathrm{~m} / \mathrm{min}$ and (b) $5 \mathrm{~m} / \mathrm{min}$

직사각형 형태를 이룬다. 또한 $\mathrm{FZ}$ 하부의 $\mathrm{HAZ}$ 부위는 입도 $1 \mathrm{~mm}$ 이하의 등축정 입자로 구성된다.

클래딩 용접 부위 별 경도값은 $\mathrm{FZ}$ 이 $396 \mathrm{HV} / 421 \mathrm{HV}$ 로 측정되며, HAZ는 FZ 쪽과 모재 쪽이 $440 \mathrm{HV} / 444 \mathrm{HV}$ 와 $194 \mathrm{HV}$ 로 완전하게 구분되어 측정된다. 즉 $\mathrm{HAZ}$ 부위 별 경도는 Fig. 8 (b)의 2번 시편에서와 같이 $\mathrm{FZ}$ 쪽 부위의 (2)는 $444 \mathrm{HV}$ 이고 모재 쪽 부위의 (3)은 $225 \mathrm{HV}$ 로 모재의 $194 \mathrm{HV}$ 와 유사하게 측정되어 $\mathrm{FZ}$ 및 $\mathrm{BM}$ 의 $\mathrm{HAZ}$ 부위가 극명하게 구분되는 것을 알 수 있 다. 여기에서 $\mathrm{FZ}$ 쪽 $\mathrm{HAZ}$ 경도값 $444 \mathrm{HV}$ 가 $\mathrm{BM}$ 쪽 $\mathrm{HAZ}$ 경도값 $225 \mathrm{HV}$ 보다 높은 것은 $\mathrm{FZ}$ 의 $\mathrm{Ti}-6 \mathrm{Al}-4 \mathrm{~V}$ 합금 성분이 기판인 $\mathrm{BM}$ 의 순수 $\mathrm{Ti}$ 에 비하여 $\mathrm{HAZ}$ 쪽 으로 확산되고 고용경화유발 효과에 기인하는 것으로 판단된다.

\subsection{Ti-6Al-4V (Grade 5) 클래딩 미세조직}

Fig. 3 (b)의 왼쪽 1 번 미세조직은 Fig. 9와 같다. Fig. 9에서 FZ 부위인 (1)과 (2)의 경우 a-lath 조직으 로 관찰된다. 그런데 $\mathrm{FZ}$ 상부인 (1) 위치는 (2) 위치보

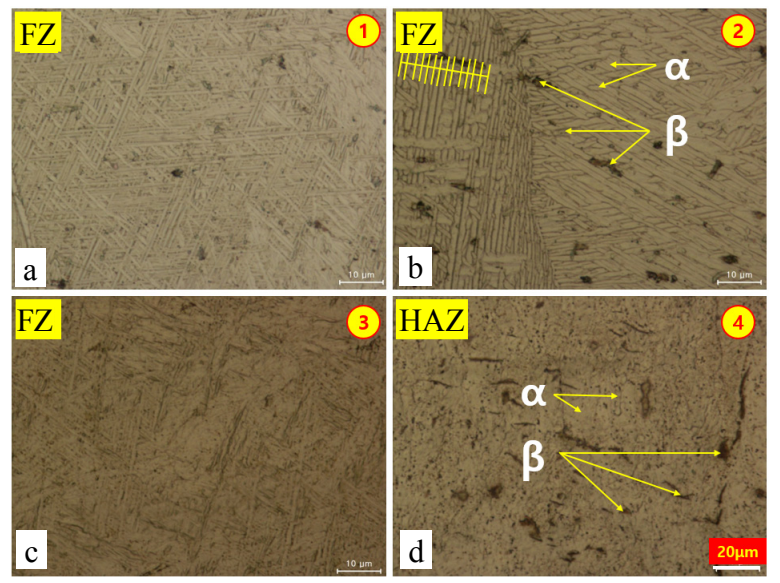

Fig. 9 Microstructures of Ti-6Al-4V GTAW cladding for 2m/ min : (a),(b), (c) FZ and (d) HAZ 


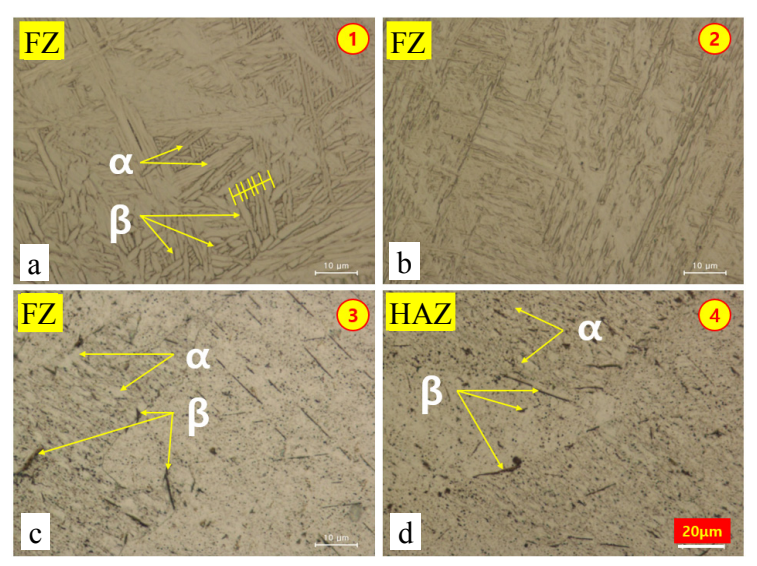

Fig. 10 Microstructures of Ti-6Al-4V GTAW cladding for $5 \mathrm{~m} / \mathrm{min}:$ (a),(b),(c) FZ and (d) HAZ

다 lath 간격이 작은데, (2) 위치의 a-lath 간격은 평균 $1.5 \mu \mathrm{m}$ 인 것으로 측정된다. 또한 이 부위의 lath 경계에 흑색의 $\beta$ 상 형성이 관찰된다. FZ line 직상의 (3) 위치 에서는 (1) 위치와 유사한 간격의 a-lath 조직이 관찰되 며, 모재에 인접한 HAZ의 (4) 위치에서는 $a$ 상 기지조 직 입계에 흑색의 $\beta$ 상이 석출한 형태로 관찰된다.

Fig. 3 (b)의 오른쪽 2 번 미세조직은 Fig. 10 과 같 다. Fig. 10에서 FZ 부위인 (1)의 경우 a-lath 조직으 로 관찰되는데, lath 간격은 평균 $1.6 \mu \mathrm{m}$ 인 것으로 측정 되어 앞의 Fig. 3 (b)의 왼쪽 1 번 경우와 거의 유사한 것을 알 수 있다. 또한 FZ line 직상의 (2) 위치에서는 (1) 위치와 유사한 $a-l a t h$ 조직이 관찰된다. 그런데 $\mathrm{FZ}$ line 직하인 HAZ의 (3) 위치에서는 Fig. 10 (c)와 같 이 a-lath 유사 조직과 상의 석출조직이 공통으로 관찰 된다. 이것은 $\mathrm{FZ}$ 부근의 $\mathrm{HAZ}$ 상부에 용접열이 용융과 응고 영향이 가해진 것으로 보여 진다. 또한 모재에 인 접한 HAZ의 (4) 위치에서는 Fig. 10 (d)와 같이 $a$ 상
기지조직 입계에 흑색의 $\beta$ 상이 석출한 형태로 관찰된 다. 이것은 Fig. 3 (b)의 왼쪽 1 번 시편과 유사한 미 세조직 구성이다.

\section{6 순수 $\mathrm{Ti}$ 클래딩의 SEM 미세조직 및 성분 분석}

순수 Ti GTAW 클래딩 미세조직에 대하여 a-lath와 lath 경계 $\beta$ 상의 형성을 $\mathrm{SEM} / \mathrm{EDS}$ 로 분석하였다.

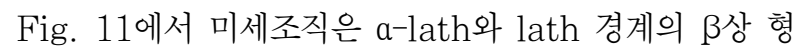
성 지역으로 구성되는 것으로 관찰되는데, 이러한 $a^{-}$ lath와 $\beta$ 상 형성 지역에서 측정되는 성분의 차이가 있 는 것을 알 수 있다. 즉 $\mathrm{SEM} / \mathrm{EDS}$ 로 측정되는 $\mathrm{a}^{-}$ lath 화학성분은 $\mathrm{Ti}-6.64 \mathrm{O}-0.34 \mathrm{Fe}$ 이며 $\beta$ 상 형성 지 역 화학성분은 $\mathrm{Ti}-9.98 \mathrm{O}-3.25 \mathrm{Fe}$ 인데, 이것으로부터 lath 경계의 $\beta$ 상 형성 지역의 불순물인 $\mathrm{O}$ 및 $\mathrm{Fe}$ 성분 이 많은 것을 알 수 있다. 그런데 SEM/EDS 분석 한 계를 고려하면 산소량이 실제보다 과다하게 산출된 것 으로 보이지만, $\alpha$ 상과 $\beta$ 상의 산소 함량은 상대적으로 “a상 < $\beta$ 상”인 것을 확인할 수 있다. 특히 $\mathrm{Fe}$ 는 $a$ 상보 다 $\beta$ 상 형성 지역에서 훨씬 많은 양이 검출되어 산소나 $\mathrm{Fe}$ 같은 불순물들이 $\beta$ 상 형성 지역에 집적된 것이 확 인된다.

\subsection{Ti-6Al-4V 클래딩의 SEM 미세조직 및 성분 분석}

Ti-6Al-4V GTAW 클래딩 재질 미세조직에 대하여 $a-l a t h$ 와 lath 경계의 $\beta$ 상 형성을 $\mathrm{SEM} / \mathrm{EDS}$ 로 분석 하였다. Fig. 12에서 미세조직은 순수 $\mathrm{Ti}$ 와 마찬가지로 $\mathrm{a}-\mathrm{lath}$ 와 lath 경계의 $\beta$ 상 형성 지역으로 구성된다. $a$ 상 화학성분은 [Ti-5.08Al-3.02V/Ti-5.35Al-3.78V]
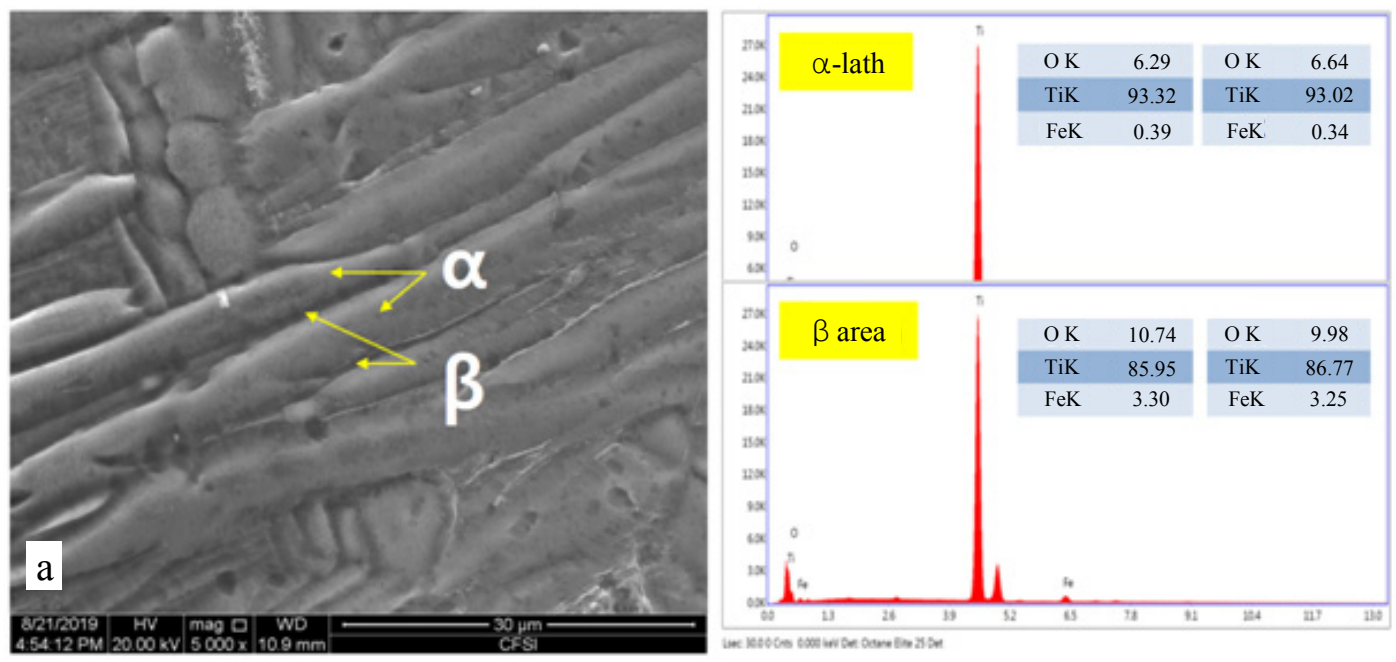

Fig. 11 SEM/EDS analysis of pure Ti GTAW cladding 

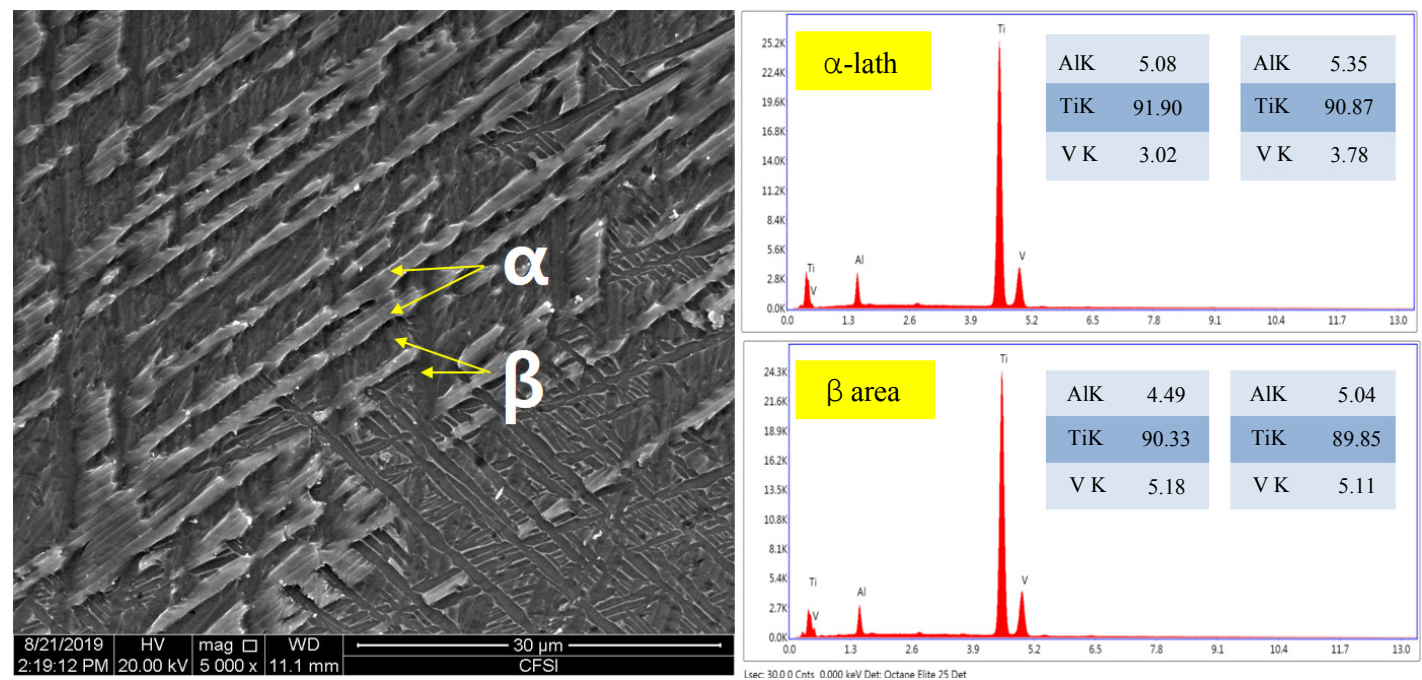

Fig. 12 SEM/EDS analysis of Ti-6Al-4V GTAW cladding

이며 $\beta$ 상 화학성분은 $[\mathrm{Ti}-4.49 \mathrm{Al}-5.18 \mathrm{~V} / \mathrm{Ti}-5.05 \mathrm{Al}-$ $5.11 \mathrm{~V}$ 으로 두 상은 $\mathrm{V}$ 함량에 차이를 보인다. 이것으 로부터 a-lath 경계에는 $\beta$ 상 형성 원소인 $\mathrm{V}$ 이 집적되 어 있는 것을 알 수 있다.

이러한 $\mathrm{SEM} / \mathrm{EDS}$ 분석 결과로부터 클래딩 소재인 $\mathrm{Ti}$ 및 $\mathrm{Ti}-6 \mathrm{Al}-4 \mathrm{~V}$ 와이어에 포함된 산소와 $\mathrm{Fe}$ 같은 불 순물이나 $\mathrm{V}$ 같은 용질 원자는 $a-l a t h$ 경계의 $\beta$ 상 형성 지역에 집적되는 것을 알 수 있다. 클래딩 소재인 $\mathrm{Ti}$ 와이 어 성분 중에 $\mathrm{Fe}$ 는 불순물 수준으로 포함되며 $(0.01 \%$ 미만), 산소는 클래딩 용접 과정 중 용융 금속에 용해 되어 불순물로 포함된다 ${ }^{9,10)}$. 또한 $\mathrm{Ti}-6 \mathrm{Al}-4 \mathrm{~V}$ 와이어 재질의 $\mathrm{V}$ 은 조성 원소로 포함되는데, 이들 불순물들과 용질 원소 $\mathrm{V}$ 은 용융 후 냉각 과정 동안 $\mathrm{a}$ 상 덴드라이 트의 경계인 인터 덴드라이트에 집적된다. 이것이 $a^{-}$ lath 구조이며 a-lath 경계가 불술물 집적 지역인 인터 덴드라이트에 해당한다. 이 때 $\mathrm{a}$ 상은 순수 $\mathrm{Ti}$ 또는 $\mathrm{Ti}-\mathrm{Al}$ 성분으로 구성되고 $\beta$ 상은 $\mathrm{O}, \mathrm{Fe}$ 불순물 또는 $\mathrm{V}$ 용질 원자 집적 성분으로 구성된다.

\section{4. 결 론}

1) 순수 Ti GTAW 클래딩에서 FZ (fusion zone) 및 HAZ (heat affected zone) 미세조직은 Pure Ti 성분의 $a$ 상과 불순물인 $\mathrm{Fe}$-rich 성분 $\beta$ 상의 라멜라 적 층 조직으로 구성된다.

2) 순수 Ti GTAW 클래딩에서 라멜라 간격은 5-10 $\mu \mathrm{m}$ 폭의 $\mathrm{FZ}$ 보다 4-5 $\mu \mathrm{m}$ 폭의 $\mathrm{HAZ}$ 지역이 미세하게 관찰 되었는데, 이것은 $\mathrm{HAZ}$ 냉각속도가 $\mathrm{FZ}$ 보다 빠른 것에 기인한다.

3) $\mathrm{Ti}-6 \mathrm{Al}-4 \mathrm{~V}$ GTAW 클래딩에서 FZ의 미세조직은
V-rich a상과 V-lean $\beta$ 상의 라멜라 조직으로 구성된 다. 라멜라 간격은 $1.5 \mu \mathrm{m}$ 폭으로 측정된다.

4) $\mathrm{Ti}-6 \mathrm{Al}-4 \mathrm{~V}$ GTAW 클래딩에서 HAZ미세조직은 $a$ 상 기지조직에 길이 $10 \mu \mathrm{m}$ 이하 정도의 긴 $\beta$ 상 석출 조직으로 관찰된다.

5) Ti-6Al-4V GTAW 클래딩에서 FZ/HAZ1/ HAZ2/ $\mathrm{BM}$ 경도는 421/444/225/194HV 로써 $\mathrm{FZ}$ 방향의 $\mathrm{HAZ}$ 경도는 $\mathrm{FZ}$ 에 비교하여 크지만, 모재 (BM, base metal) 경도는 $\mathrm{BM}$ 에 준하여 낮은 것을 알 수 있다. 이러한 이유는 $\mathrm{HAZ}$ 경도가 $\mathrm{Ti}-6 \mathrm{Al}-4 \mathrm{~V}$ 성분의 $\mathrm{FZ}$ 와 순수 $\mathrm{Ti}$ 성분의 $\mathrm{BM}$ 확산에 영향을 받았기 때문인 것 으로 판단된다.

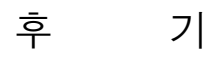

본 연구는 강릉원주대학교 중소기업산학협력센터의 지원사업으로 수행되었습니다.

ORCID: Byung Hak Choe: http://orcid.org/0000-0002-2859-6489

\section{References}

1. I. Uygur and I. Dogan, The Effect of TIG Welding on Microstructure and Mechanical Properties of a ButtJointed-Unalloyed Titanium, Metalurgija, (Metallurgical), Metall. 44 (2) (2005) 119-123.

2. X. Li, J. Xie and Y. Zhou, Effects of Oxygen Contamination in the Argon Shielding Gas in Laser Welding of Commercially Pure Titanium Thin Sheet, J. Mater. Sci., 40 (13) (2005) 3437-3443. https://doi.org/10.1007/s10853-005-0447-8

3. B. Banu, M. Sc. Thesis, Effects of Gas Shielding Flow Rate on Weld Quality of TIG Welding in Ti6Al4V Alloy, Istanbul Technical University, Istanbul, Maslak 
(2012) 103.

4. A. Karpagaraj, N. Siva Shanmugam and K. Sankaranarayanasami, The Effect of Process Parameters on TIG Welding of Thin Ti-6Al-4V Sheets, Int. J. Mech. Prod. Eng. 2 (10) (2014) 49-52.

5. Y. Lu, M. Phi. D. Thesis, The Effects of Inter-pass Temperature on the Microstructure and Mechanical Properties of Ti-6Al-4V Alloy Deposited by Wire Arc Additive Manufacturing(WAAM), University of Wollongong, Wollongong, Australia (2018) 116.

6. X. Su, W. Tao, Y. Chen and J. Fu, Microstructure and Tensile Property of the joint of Laser-MIG Hybrid Welded Thick-section TC4 Alloy, Metals (Basel), 8 (12) (2018) 1002.

https://doi.org/10.3390/met8121002
7. C. Charles, Licentiate Thesis, Modelling Microstructure Evolution of Weld Deposited Ti-6Al-4V, Lulea University of Technology, Sweden, Lulea (2008) 28.

8. C. C. Murgau, Ph. D. Thesis, Microstructure Model for Ti-6Al-4V used in Simulation of Additive Manufacturing, Lulea University of Technology, Sweden, Lulea (2016) 159.

9. P. Danielson, R. Wilson and D. Alman, Microstructure of Titanium Welds, $A M \& P, 161$ (2) (2003) 39-42.

10. J. A. Garcia, G. L. Lima, W. D. B. Pereira, V. A. Guimaraes, C. Moura Neto and R. P. R. Paranhos, Characterization of Titanium Welded Joint by the Gas Tungsten Arc Welding Process for Aerospace Application, J. Aerosp. Technol. Manag. 2 (2) (2010) 211-218.

https://doi.org/10.5028/jatm.2010.02026710 